\title{
Natural Habitats of Lycopersicon Species
}

\author{
S.J. Warnock \\ Campbell Institute for Research \& Technology, 28605 County Road No. 104, Davis, CA 95616
}

Broadening the limited genetic base of the domestic tomato, Lycopersicon esculentum Mill., has become an important research goal in recent years. Efforts have been expanded to transfer genetic characteristics from wild Lycopersicon spp. into the domestic tomato. New techniques and recognition of the broad range of valuable characteristics in wild species have fueled this work. Considerable collection work has been done and incidental comments have been made in the literature, but no critical evaluation of habitats has been made. Recent collectors, aside from locating collections, have provided an idea of the altitude(Cuartero et al., 1984, 1985; Delgado de la Flor, 1988; Hone et al., 1978, 1979), associated flora (Cuartero et al., 1984, 1985), and some general observations on habitats (Hone et al., 1978, 1979). Unfortunately, information relating taxa and intraspecific types to rainfall, temperatures, and edaphic conditions is lacking.

All eight wild species of tomatoes as well as the wild form of $L$. esculentum have natural habitats on the west coast of South America from southern Ecuador to northern Chile ( $\approx 0^{\circ}$ to $23^{\circ} \mathrm{S}$ latitude) and in the Galapagos Islands (Fig. 1). The geography of this expanse is highly varied. Terrain on the mainland extends from sea level to $>6500$ $\mathrm{m}$. Tosi (1960) listed 35 distinctive ecological formations for Peru alone, and Weberbauer (1936) mapped 25. Collections of wild Lycopersicon have been reported from sea level to as high as $3700 \mathrm{~m}$ (Hone et al., 1978). The eight wild Lycopersicon spp. plus the wild form of $L$. esculentum are highly variable, a reflection of the varied environment.

Rick (1976a) suggested knowledge of autecology to be valuable for determining genetic value. Knowledge of habitats of Lycopersicon collections elucidates the relationships of these species to their environment, and specific information on habitats provides insight into the value of collections as genetic sources for domestic tomato improvement. It is the purpose of this paper to review present habitat information, available rainfall and temperature data, and to highlight gaps in available information for the

Received for publication 13 Mar. 1990. I thank Dennis Larsen for assistance in preparation of the figures. The cost of publishing this paper was defrayed in part by the payment of page charges. Under postal regulations, this paper therefore must be hereby marked advertisement solely to indicate this fact. various Lycopersicon spp. I would also like to convey an appreciation of the great diversity of the habitats and the concomitant diversity of the species.

\section{Geographic characteristics}

The west coast of South America is characterized by the Andes, a north-south cordillera. Elevations between $0^{\circ}$ and $23^{\circ} \mathrm{S}$ latitude reach $6500 \mathrm{~m}$, but the Andes are considerably lower than this in northern Peru east of Olmos. Major rivers of the eastern (Atlantic) drainage flow longitudinally south to north between the ranges and eventually turn east to the Atlantic. An exception is the Mantaro River, which initially flows south but subsequently turns north and then east. The west slope of the Andes is dissected by valleys formed by westwardly flowing rivers that have short steep courses and empty into the Pacific Ocean. Some 50 of these rivers occur on the west coast of Peru. Tosi (1960) designated 22 of these Peruvian rivers as principal and permanent. The remainder are either permanent with low winter flow or intermittent. River valleys are separated by high ridges of the Andes that approach or reach the sea, and as a result they are isolated one from another.

The Peru Current borders the west coast of South America. It arises in the cold waters of the high southern latitudes of the Pacific Ocean and flows along the coast to $\approx 5^{\circ} \mathrm{S}$ latitude, where it turns northwest, then west.

The Galapagos are a group of volcanic islands in the Pacific Ocean $1100 \mathrm{~km}$ west of the coast of South America on the equator. Elevations in the islands do not exceed $1700 \mathrm{~m}$. These islands lie in the westward flow of the Peru Current.

\section{General climatic characteristics}

The climate of the area (Fig. 1) under consideration is basically tropical but strongly modified by topography and geophysical events. Moist tropical maritime and equa-

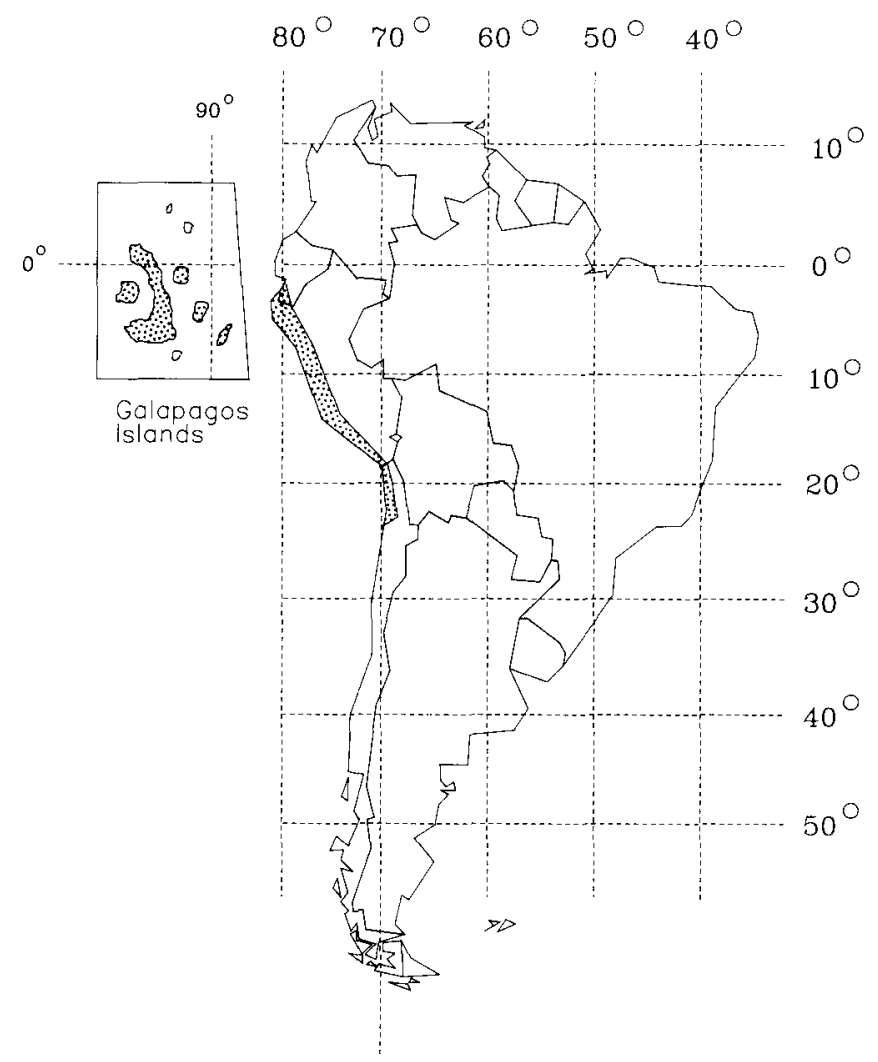

Fig. 1. Map of South America and the Galapagos Islands indicating the general area (shaded) of distribution of Lycopersicon spp. Seven of the eight wild species of Lycopersicon occur on the continent. An eighth wild species, L. cheesmanii, inhabits the Galapagos Islands. 
torial air masses yielding heavy rainfall are the principal sources of precipitation in the Andes (Barry and Chorley, 1987). Storms move westerly from the Atlantic Ocean. Rainfall from these air masses diminishes with increased elevation. Intermountain areas in the lee of storms maybe in rain shadows and quite arid. The Pacific slope receives precipitation from these storms, but rainfall diminishes beyond the vertex irrespective of elevation. Rainfall follows the same annual fluctuation throughout the area (Fig. 2). These storms seldom, if ever, result in precipitation on the coastal area. Rainfall seasonality is imposed on the intermountain area by encroachment in the winter, east of the Andes, of drier continental tropical air masses from the south that block storms of the tropical maritime and equatorial systems (Barry and Chorley, 1987). This blocking effect is less intense closer to the equator. In Ecuador, the Pacific slope is affected by the Intertropical Convergence in the Pacific Ocean and receives rain from Pacific marine air.

The coastal areas of Chile and Peru are strongly influenced by the Peru Current, producing a coastal climate in a narrow band 30 to $100 \mathrm{~km}$ wide. A warm anomaly in the Peru Current occurs in the bight near Arica, in northern Chile (Bakun and Parrish, 1982). This phenomenon is intensified in the winter and tends to abate in the summer. The anomaly induces an onshore flow of warm air, with the result that Arica has a mean annual temperature higher than Lima. Some effect of the coastal climate may move inland and spill into the intermountain valleys, particularly in northern Peru and southern Ecuador (Barry and Chorley, 1987). The coastal area of the northern portion of this region is also affected by El Nino-Southem Oscillation. This oscillation, a weak southerly flow of warm water to $\approx 6^{\circ} \mathrm{S}$, develops annually along the coast of Ecuador and Peru, usually in December (Barry and Chorley, 1987). This event becomes more extensive and intense at highly irregular intervals, resulting in marked changes in the weather of southern Ecuador and northern Peru. Less-severe events are interspersed with more-severe ones, resulting in an average occurrence interval for noteworthy ones of $\approx 3$ years. This Southern Oscillation allows the Intertropical Conver- gence and its associated rainfall to extend southward into Peru. Older local inhabitants affirm that this event extended as far south as Trujillo $\left(8^{\circ} \mathrm{S}\right)$ in $1925-26$.

\section{Temperatures}

The most accurate and readily available temperature data for the area are the 10-year averages published by the U.S. Commerce Dept. Temperature data used in this manuscript are the 1961-70 averages (U.S. Dept. of Commerce, 1982), except as noted. Tosi (1960) gives rainfall and temperature data for various locations in Peru. He notes that records mostly were taken over short periods and that the data contained some very obvious inaccuracies.

Annual temperature fluctuation tends to be least at the equator. Quito, Ecuador, has a mean monthly variation of $\approx 1 \mathrm{C}$ throughout the year, while at $\mathrm{La} \mathrm{Paz}$, Bolivia, at $16^{\circ}$ $25^{\prime} \mathrm{S}$ there is an annual fluctuation in monthly means of $3.4 \mathrm{C}$.

There is a markedly seasonality induced by the Peru Current in the coastal area, and a lag in seasonality for winter and summer occurs as the current progresses north. From 1961 to 1970 (U.S. Dept. Comm., 1982), the coolest month of the year at Antofagasta, Chile, was July (Table 1). Lima was coolest

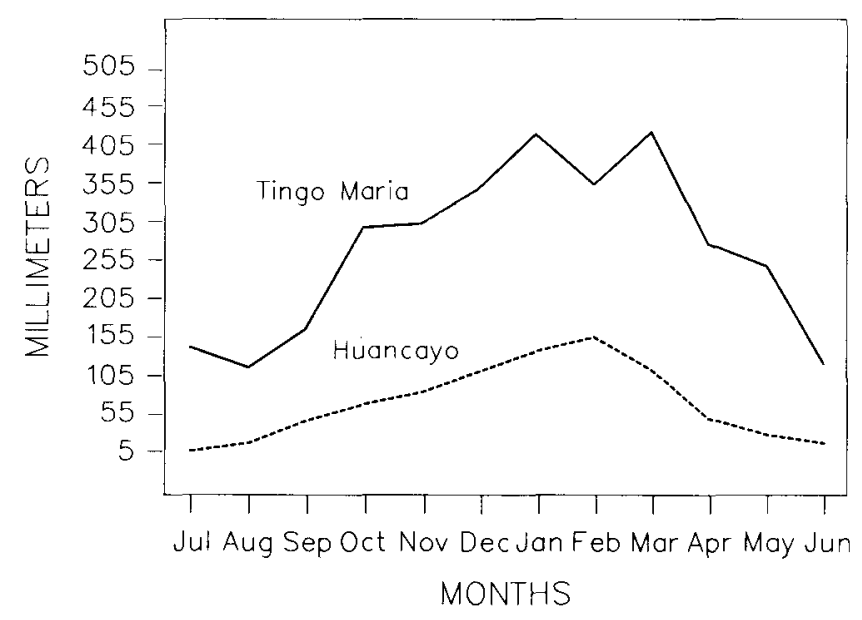

Fig. 2. Mean monthly rainfall at Tingo Maria and Huancayo (elevation 641 and $3350 \mathrm{~m}$, respectively), Peru, for 1951-60 (U.S. Dept. of Comm., 1966). in July and August, and at Trujillo (on partial records) the lowest temperature occurred in August. The coolest month at Talara was September. The highest temperatures for each location were in January from $53^{\circ}$ to $18^{\circ} \mathrm{S}$, but were skewed toward autumn (February, March) at lower latitudes (Table 1). There is a greater fluctuation in temperature from summer to winter in the coastal area than in the intermountain area, the coastal fluctuation being $\approx 6 \mathrm{C}$.

Temperature decreases with increased altitude in the inland areas, the decrease averaging $1 \mathrm{C}$ for each $200 \mathrm{~m}$ of elevation. The lapse rate of temperature fluctuates from summer to winter, tending to be less in winter months (Barry and Chorley, 1987). The lapse rate can be used to estimate temperatures for the eastern Andes and the higher elevations of the western Andes. However, the lapse rate is not pertinent for west coast locations at lower elevations because of an inversion caused by the Peru Current. This inversion occurs at 600 to $1500 \mathrm{~m}$, the normal lapse rate being reestablished above this inversion (Barry and Chorley, 1987; Flohn, 1969).

Using seven low elevation and seven high elevation stations in Ecuador, Peru, and Bolivia east of the Andes, I determined the lapse rate of temperature from annual means. This

Table 1. Mean monthly temperatures for 1961 through 1970 for various locations on the west coast of South America (U.S. Dept. of Comm., 1982) ${ }^{2}$. The highest and lowest monthly temperatures for each location have been underlined.

\begin{tabular}{|c|c|c|c|c|c|c|c|c|c|c|c|c|c|c|c|c|}
\hline \multirow[b]{2}{*}{ Location $^{y}$} & \multirow[b]{2}{*}{ Lat.S } & \multirow[b]{2}{*}{ Long.W } & \multirow{2}{*}{$\begin{array}{c}\text { Elev. } \\
\text { (m) }\end{array}$} & \multicolumn{12}{|c|}{ Mean temperature $\left({ }^{\circ} \mathrm{C}\right)$} & \multirow{2}{*}{$\begin{array}{r}\text { _Annua } \\
\text { mean }\end{array}$} \\
\hline & & & & Jan. & Feb. & Mar. & Apr. & May & June & July & Aug. & Sept. & Oct. & Nov. & Dec. & \\
\hline \multicolumn{17}{|l|}{ Punta Arenas/ } \\
\hline Chabunco & $53^{\circ} 00^{\prime}$ & $70^{\circ} 50^{\prime}$ & 30 & 10.4 & 10.0 & 8.4 & 5.8 & 3.7 & 1.7 & 1.3 & 2.2 & 4.0 & 6.2 & 8.4 & 9.7 & 6.0 \\
\hline Santiago & $33^{\circ} 27^{\prime}$ & $70^{\circ} 42^{\prime}$ & 520 & $\overline{21.2}$ & 20.0 & 17.7 & 14.4 & 11.3 & 8.2 & $\overline{8.1}$ & 9.4 & 11.4 & 14.3 & 17.2 & 19.8 & 14.4 \\
\hline \multicolumn{17}{|c|}{ Valparaiso/Punta } \\
\hline Ángeles & $33^{\circ} 01^{\prime}$ & $71^{\circ} 38^{\prime}$ & 40 & 17.6 & 17.2 & 15.9 & 14.3 & 13.3 & 11.8 & 11.3 & 11.5 & 11.8 & 13.3 & 15.2 & 16.6 & 14.2 \\
\hline Antofagasta & $23^{\circ} 28^{\prime}$ & $70^{\circ} 26^{\prime}$ & 130 & $\overline{19.8}$ & 19.7 & 18.5 & 16.8 & 15.2 & 13.8 & $\overline{13.2}$ & 13.5 & 14.1 & 15.2 & 16.7 & 18.4 & 16.2 \\
\hline Arica & $18^{\circ} 29^{\prime}$ & $70^{\circ} 19^{\prime}$ & 40 & 21.6 & 21.9 & 21.3 & 19.4 & 17.4 & 16.0 & 15.2 & 15.3 & 16.0 & 17.2 & 18.8 & 20.3 & 18.4 \\
\hline \multicolumn{17}{|c|}{ Lima/Campo del } \\
\hline Marte & $12^{\circ} 04^{\prime}$ & $77^{\circ} 55^{\prime}$ & 130 & 21.3 & 22.0 & 21.8 & 20.2 & 17.9 & 16.0 & 14.9 & 14.9 & 15.0 & 16.0 & 17.4 & 19.3 & 18.1 \\
\hline Trujillo & $8^{\circ} 06^{\prime}$ & $79^{\circ} 05^{\prime}$ & 30 & 21.5 & $\overline{21.8}$ & 20.8 & 20.1 & 18.3 & 17.5 & $\overline{17.3}$ & $\overline{16.7}$ & 16.9 & 17.0 & 18.1 & 19.2 & 19.3 \\
\hline Talara/Corpac & $4^{\circ} 34^{\prime}$ & $81^{\circ} 15^{\prime}$ & 80 & 23.9 & 24.8 & 24.9 & 24.0 & 22.1 & 20.0 & 18.5 & 18.5 & 18.3 & 18.8 & 19.7 & 21.5 & 21.3 \\
\hline
\end{tabular}

${ }^{2}$ Means for Trujillo are for the period 1 July 1961 to 31 Dec. 1964 (recorded by the author).

Latitudes above $18^{\circ} \mathrm{S}$ are in Chile and those below in Peru. 
Table 2. Monthly and annual mean isothermal temperatures for various altitudes in inter-Andean South America from latitude $0^{\circ}$ to $23^{\circ} \mathrm{S}$.

\begin{tabular}{|c|c|c|c|c|c|c|c|c|c|c|c|c|c|}
\hline \multirow{2}{*}{$\begin{array}{l}\text { Elevation } \\
(\mathrm{m}) \\
\end{array}$} & \multicolumn{12}{|c|}{ Mean temperature $\left({ }^{\circ} \mathrm{C}\right)$} & \multirow[b]{2}{*}{ Mean } \\
\hline & January & February & March & April & May & June & July & August & September & October & November & December & \\
\hline 500 & 25.4 & 25.9 & 25.0 & 24.8 & 23.9 & 22.0 & 22.4 & 24.2 & 25.8 & 26.3 & 26.5 & 26.3 & 24.9 \\
\hline 1000 & 22.9 & 23.3 & 22.5 & 22.4 & 21.6 & 19.9 & 20.2 & 21.8 & 23.2 & 23.7 & 23.9 & 23.7 & 22.4 \\
\hline 1500 & 20.4 & 20.7 & 20.0 & 20.0 & 19.3 & 17.8 & 18.0 & 19.4 & 20.6 & 21.1 & 21.3 & 21.1 & 19.9 \\
\hline 2000 & 17.9 & 18.1 & 17.5 & 17.6 & 17.0 & 15.7 & 15.8 & 17.0 & 18.0 & 18.5 & 18.7 & 18.5 & 17.4 \\
\hline 2500 & 15.4 & 15.5 & 15.0 & 15.2 & 14.7 & 13.6 & 13.6 & 14.6 & 15.4 & 15.9 & 16.1 & 15.9 & 14.9 \\
\hline 3000 & 12.9 & 12.9 & 12.5 & 12.8 & 12.4 & 11.5 & 11.4 & 12.2 & 12.8 & 13.3 & 13.5 & 13.3 & 12.4 \\
\hline 3500 & 10.4 & 10.3 & 10.0 & 10.4 & 10.1 & 9.4 & 9.2 & 9.8 & 10.2 & 10.7 & 10.9 & 10.7 & 9.9 \\
\hline 4000 & 7.9 & 7.7 & 7.5 & 8.0 & 7.8 & 7.3 & 7.0 & 7.4 & 7.6 & 8.1 & 8.3 & 8.1 & 7.4 \\
\hline Lapse rate & 0.99 & 1.04 & 0.99 & 0.96 & 0.92 & 0.82 & 0.87 & 0.97 & 1.05 & 1.04 & 1.05 & 1.06 & 0.99 \\
\hline
\end{tabular}

${ }^{2}$ Per $200 \mathrm{~m}$.

lapse rate was $0.99 \mathrm{C}$ per $200 \mathrm{~m}$, a value essentially identical to the standard $1 \mathrm{C}$ for $200 \mathrm{~m}$. Subsequently, I calculated the lapse rate for the mean monthly temperatures. These followed expectations also, with winter months having lower lapse rates than summer months. Using these lapse rates and the mean temperatures for the lower elevation stations, I calculated isothermal temperatures for 500-m intervals (Table 2). These isothermal temperatures, coupled with elevation reports for tomato collections, provide information on temperature conditions in areas of collection outside the coastal area.

Diurnal temperatures are less well-documented than monthly and annual means. Barry and Chorley (1987) suggest variations of $\approx 10$ to $14 \mathrm{C}$ in the tropics. My experience at Trujillo suggested about the same, 10 to $15 \mathrm{C}$. Slightly higher or lower variations may occur in isolated places and times.

Climatic data from the Galapagos are not readily available. The island is washed by the Peru Current, which undoubtedly moderates the climate. Rick (1956) describes the climate as mild and cloudy. J.T. Landivar (personal communication) described the climate as cool-temperate throughout the year, with limited rainfall, but with slightly more rainfall from November to May than during the other half of the year. He was unable to provide specific weather data. A mean annual temperature for the Galapagos (at sea level) probably lies between the mean annual temperature of Talara, Peru (21 .3 C), and that of Guayaquil, Ecuador (25.5 C).

\section{Rainfall}

Rainfall data for Peru were not reported for the 1960-1971 decade; hence, rainfall data I used are the 1951-1960 averages (U.S. Dept. Comm., 1966), except as noted. Rainfall varies markedly from north to south and east to west (Table 3). Condensate from fog is the principal source of precipitation in the coastal area. Rainfall from orographic enhancement of Pacific marine air may occur inland, but is difficult to distinguish from rain from eastern storms cresting the Andes (Tosi, 1960). Precipitation from fog generally is very light in unexposed areas, but it can be particularly heavy in elevated areas or exposed outcrops. Records (Tosi, 1960) for the Lomas de Lachay (380 m) (lying between Chancay and Huacho, Peru) for 19311954 indicate annual average precipitation of
$210 \mathrm{~mm}$, with $87 \%$ occurring in the colder period from June to November. In contrast, average precipitation at Paramonga $(15 \mathrm{~m}$ elevation) to the north and at La Punta (15 $\mathrm{m}$ elevation) to the south was 24 and $10 \mathrm{~mm}$, respectively. In the north coastal area, rainfall can be highly variable because of the influence of El Nine. Annual rainfall at Zorritos, Peru, has varied from 0 to 1500 $\mathrm{mm} \cdot$ year $^{-1}$ (Tosi, 1960).

Precipitation increases inland. Annual amounts average $125 \mathrm{~mm}$ (Tosi, 1960) in the elevated area immediately adjacent to the coastal belt, and amounts increase at the higher elevations. Tosi (1960) listed interAndean locations with a range of 236 to 1388 $\mathrm{mm}$. Because of moderate temperatures and frequent cloudy weather, evaporation is undoubtedly low.

\section{Edaphic variation}

Indications are that valleys of westerly flowing rivers may have unique edaphic characteristics. One clue is dedication of arable land in valleys to specific crops. For example, the Jequetepeque tends to be dedicated to rice, the Chicama, Santa Catalina, and Fortaleza to sugarcane, the Viru to corn, and the Santa and Canete to cotton. Obviously, other factors influence this dedication, but it appears edaphic conditions have played a role in the empirical selection of a dominant crop. The average soil $\mathrm{pH}$ of the delta area of each valley tends to be related to the amount of water that flows in the valley. The greater the flow, the lower the $\mathrm{pH}$. Furthermore, the $\mathrm{pH}$ steadily increases from the upper delta area to the ocean (unpublished data). Nutrient deficiencies, particularly phosphorus deficiency, occur in some valleys. Ground water emanating from copper-bearing rock is low in $\mathrm{pH}$. Rick has mentioned edaphic differences, but has not provided specifics. Edaphic information is conspicuously lacking for locations of collections, probably because many of the collections are not made on arable land.

\section{Specific habitats}

Many distinct environments exist in the area because of the intermingled and variable characteristics of the soil, temperature, precipitation, and elevation. In this highly variable milieu, the Lycopersicon spp. have evolved. While they may be sympatric in many instances, each species has a distinctly defined range different from each of the other species (Fig. 3). The species are not coextensive with the territory throughout their ranges, but tend to occur individually or in enclaves where certain environmental requirements are met.

The true natural habitat of $L$. esculentum var. cerasiforme (Dun.) Gray is difficult to

Table 3. Average annual rainfall for 1951 through 1960 at various locations in South America (U.S. Dept. of Comm., 1966).

\begin{tabular}{|c|c|c|c|c|}
\hline Location & Lat. S & Long. W & $\begin{array}{l}\text { Elevation } \\
\text { (m) }\end{array}$ & $\begin{array}{c}\text { Rainfall } \\
(\mathrm{mm})\end{array}$ \\
\hline \multicolumn{5}{|l|}{ Ecuador } \\
\hline Banos $^{z}$ & $01^{\circ} 23^{\prime}$ & $78^{\circ} 25^{\prime}$ & 1830 & 1368 \\
\hline Quito & $00^{\circ} 13^{\prime}$ & $78^{\circ} 30^{\prime}$ & 2818 & 1240 \\
\hline Guayaquil & $02^{\circ} 12^{\prime}$ & $79^{\circ} 53^{\prime}$ & 6 & 1023 \\
\hline \multicolumn{5}{|l|}{ Peru } \\
\hline Tingo Maria & $09^{\circ} 08^{\prime}$ & $75^{\circ} 57^{\prime}$ & 641 & 3193 \\
\hline Huancayo & $12^{\circ} 02^{\prime}$ & $75^{\circ} 20^{\prime}$ & 3350 & 776 \\
\hline \multicolumn{5}{|l|}{ Lima/Campo del } \\
\hline Marte & $12^{\circ} 04^{\prime}$ & $77^{\circ} 02^{\prime}$ & 137 & 22 \\
\hline \multicolumn{5}{|l|}{ Bolivia and Chile } \\
\hline Santa Cruz (Boliva) & $17^{\circ} 47^{\prime}$ & $63^{\circ} 10^{\prime}$ & 437 & 1237 \\
\hline \multicolumn{5}{|l|}{ La Paz/El Alto } \\
\hline (Bolivia) & $16^{\circ} 30^{\prime}$ & $68^{\circ} 10^{\prime}$ & 4103 & 556 \\
\hline \multicolumn{5}{|l|}{ Antofagasta } \\
\hline (Chile) & $23^{\circ} 28^{\prime}$ & $70^{\circ} 26^{\prime}$ & 122 & Trace \\
\hline
\end{tabular}

${ }^{2}$ Data for Banes are for 1961-1970 (U.S. Dept. of Comm., 1982). Quito averaged $109 \mathrm{~mm}$ less rainfall in the decade 1961-1970 than in the reported decade. 

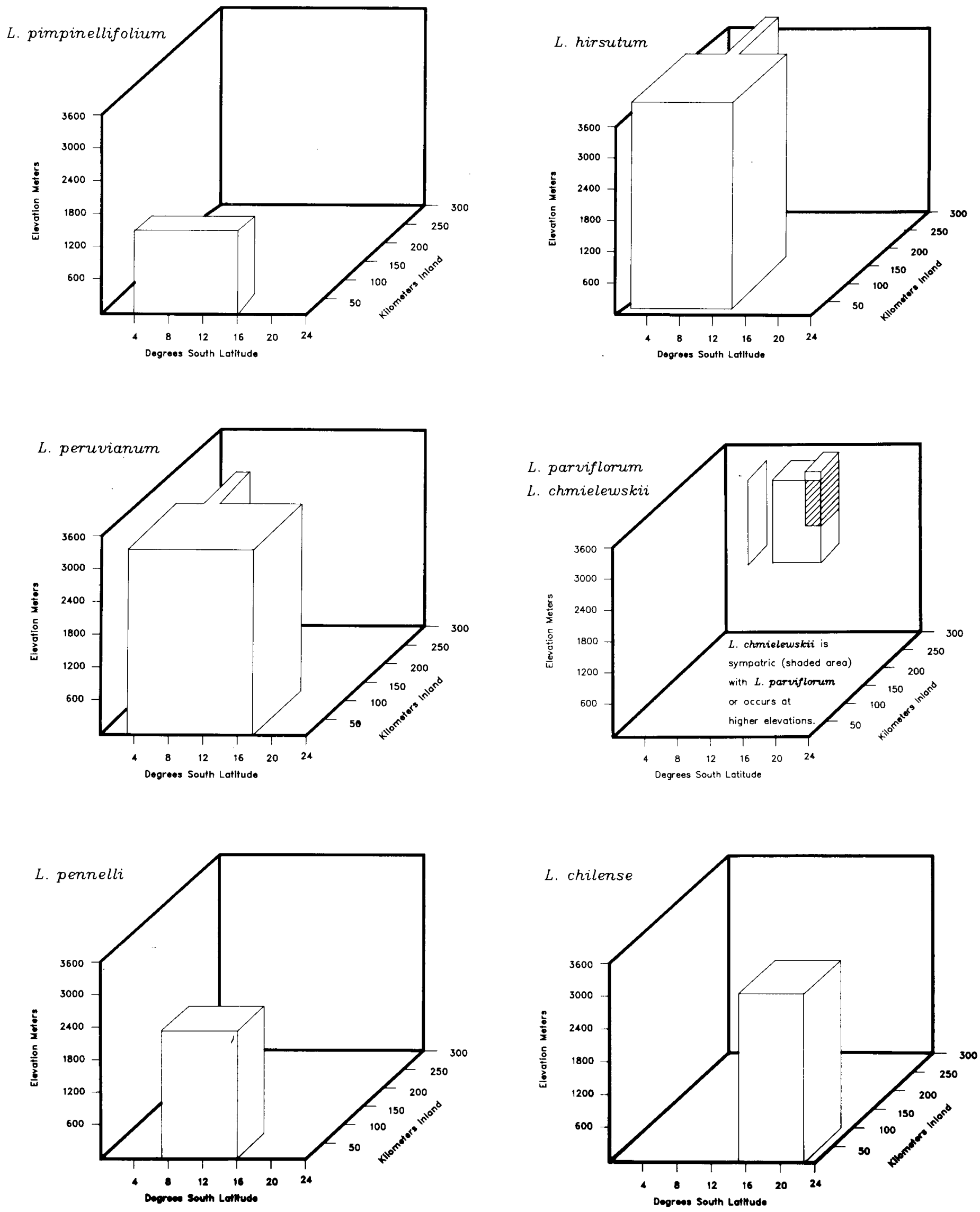

Fig. 3. Schematic representation of the habitat of seven of the eight wild species of the genus Lycopersicon. The wild habitats of these seven species are all on the west coast mainland of South America. 
define because of its aggressive colonizing tendencies and wide distribution into other parts of the world (Rick, 1976b). It is native to western South America, but as a weedy form migrated into Central America and Mexico, where it supposedly gave rise to the domestic tomato. It is now found in other parts of South America and most tropical regions of the world. Biotypes from the arid regions of Peru as well as types that survive the wet humid conditions of the eastern Andes have been collected. This latter type is an exception to the preference of tomato species for dry climates (Rick, 1978). L. esculentum var. cerasiforme has been collected from sea level to as high as $2400 \mathrm{~m}$ in South America (Cuartero et al., 1985).

The native habitat of $L$ cheesmanii Riley is confined to the Galapagos Islands. This species tends to colonize the lower arid elevations of the island, but also has been found at the middle forested elevations (Rick, 1963). Rick (1971) reported that this species occurs on tumefaceous soils and on cinder slopes in the lower and middle altitudes. Skies are overcast and temperatures mild during the time the species flourishes (Rick, 1956). The species grows in a climate of generally low rainfall and moderate to medium high temperatures (Table 4). L. cheesmanii f. minor (Hook. f.) Mull. is particularly adapted to the low elevations of the Galapagos and its range extends into the littoral zone (Rick, 1978). Rush and Epstein (1976) concluded that an ecotype from the littoral zone had a high degree of salt tolerance.

L. pimpinellifolium (Jusl.) Mill., L. hirsutum Humb. \& Bonpl., L. parviflorum (Rick, Kes., Fob. \& Hone) and L. chmielewskii (Rick, Kes., Fob. \& Hone) all tend to be mesic. L. pimpinellifolium and L. hirsutum are found at similar latitudes. However, $L$. hirsutum inhabits higher elevations, while $L$. pimpinellifolium is found at the low elevations in coastal Ecuador and Peru (Rick et al., 1979). L. hirsutum has been collected from $200 \mathrm{~m}$ in coastal Ecuador to $3700 \mathrm{~m}$ (the highest reported elevation for any $L y$ copersicon spp.) in Peru (Hone et al., 1978). Rick (1978) suggests its usual occurrence is between 500 and $3300 \mathrm{~m}$ elevation. Average annual temperatures in the domain of L. hirsutum range from $21 \mathrm{C}$ for those collections below the inversion to $10 \mathrm{C}$ at the highest elevations (Tables 1, 2, and 4). This species extends farther into Ecuador than any others and also occurs in the inter-Andean area east of Olmos ( $\left.5^{\circ} 59^{\prime} \mathrm{S}, 79^{\circ} 46^{\prime} \mathrm{W}\right)$, suggesting a tolerance of more humid conditions.

Precipitation at the low elevations of the habitat for L. hirsutum ranges from 125 to $200 \mathrm{~mm}$ (Tosi, 1960) and at the high elevations and low latitudes from 700 to 1200 mm annually (Table 3 ). Night temperatures at the high elevations are low enough, 3 to $5 \mathrm{C}$, that night chilling-resistant ecotypes of L. hirsutum have developed (Patterson, 1988; Patterson and Payne, 1983).

L. pimpinellifolium is found in uncultivated areas in the deltas of the coastal rivers and sporadically in cultivated fields. It is fre-

Table 4. Range of elevations of Lycopersicon spp. in their native habitats and associated mean annual temperatures.

\begin{tabular}{|c|c|c|}
\hline Species & $\begin{array}{c}\text { Elevation } \\
(\mathrm{m})\end{array}$ & $\begin{array}{c}\text { Temperature } \\
\left({ }^{\circ} \mathrm{C}\right)\end{array}$ \\
\hline L. pimpinellifolium & $0-1450$ & $18-21$ \\
\hline L. cheesmanii & $0-1000^{2}$ & $22-23$ \\
\hline L. hirsutum & $200-3700$ & $10-21$ \\
\hline L. pennellii & $0-2300$ & $18-20$ \\
\hline L. chmielewskii & $1900-3100$ & $12-18$ \\
\hline L. parviflorum & $1700-2800$ & $13-19$ \\
\hline L. peruvianum & $0-3300$ & $11-21$ \\
\hline L. chilense & $0-2900$ & $12-20$ \\
\hline
\end{tabular}

${ }^{2}$ Estimated.

quently found along permanent canals. Rainfall is nonexistent in much of the $L$. pimpinellifolium range, and the species occurs where condensate, flooding, or seepage provide sufficient water. Heavy rains, up to $1500 \mathrm{~mm}$ annually, occur sporadically in the northern portion of its range (Tosi, 1960). L. pimpinellifolum is found from near sea level to $1450 \mathrm{~m}$, the upper limit of its range being near the inversion level. Temperatures are moderate throughout its range (Table 4).

L. parviflorum and $L$. chmielewskii are found at the 1700 to $3100 \mathrm{~m}$ elevations of inter-Andean valleys (Rick et al., 1976). Both species occur under mesic conditions on welldrained soils, generally on slopes. L. chmielewskii tends to occupy the higher, betterdrained portion of the sites where the two species are sympatric. Conversely, in experimental culture, L. parviflorum is less tolerant of excessive watering (Rick et al., 1976). L. chmielewskii tends to be confined to a small area in south-central Peru, while $L$. parviflorum extends over several degrees of latitude (Fig. 3). Annual mean temperatures in the habitat are between $\approx 12$ and $19 \mathrm{C}$ (Table 4).

L. pennellii (Corr.) D'Arty and L. chilense Dun. exist in the very dry habitats of the south-central coast and western slope of South America. L. pennellii inhabits the central portion of this dry western slope (Rick, 1978), and occasionally is found on the lower, wetter valley floors (Hone et al., 1978; Rick and Tanksley, 1981). It tolerates drought, and such tolerance prompted $\mathrm{Yu}$ (1972) to investigate it as a source of drought tolerance for the domesticated tomato. Temperatures are moderate in the range (Table 4). L. chilense is found at the southern end of the range of the Lycopersicon spp. and inhabits the very dry area of southern Peru and northern Chile. It is generally found on the slopes and bottoms of river channels that are occasionally flooded (Rick, 1978). It has been collected from sea level to $3000 \mathrm{~m}$. Temperatures are relatively low to moderate in the area (Table 4). L. chilense tends to grow in an area parallel to the warm anomaly in the Peru Current found in the bight near Arica. Whether this is coincidental or a case of related incidence is not known.

L. peruvianum (L.) Mill. is more widespread than the other Lycopersicon spp., suggesting somewhat greater adaptation and less temperature and rainfall dependency. It extends from $4^{\circ} \mathrm{S}$ to $20 \%$ and, like L. hir- sutum, extends inland into the intermountain area of northern Peru east of Olmos. L. peruvianum is extant in the southern dry area but does not occur as far south as $L$. chilense. It inhabits the northern area sympatric with $L$. hirsutum but does not extend as far north into the humid equatorial region as does L. hirsutum. L. peruvianum has been collected from sea level to $>3000 \mathrm{~m}$. Races have developed in the western river watersheds and these may be related to edaphic differences in watersheds (Rick, 1986). Mountain races developed where there is relatively good seasonal rainfall. Generally, the mountain races are confined to areas near streams but may spread over slopes at the higher elevations (Rick, 1962). Coastal types of the species have been found where moisture seeps from permanent or irregular streams and where fog-supported vegetation grows in the coastal area (Rick, 1962). C.M. Rick (personal communication) indicated a propensity for this species to grow in the area of copper mines, which might suggest ecotypes with a tolerance of low $\mathrm{pH}$ soils. The temperature range of its habitat is from low to moderate (Table 4).

\section{DISCUSSION AND CONCLUSIONS}

Because of the highly varied topography, Lycopersicon spp. do not occur in a contiguous manner throughout their range, but rather are in isolated enclaves in locations where their adaptive needs are met. Intraspecific types occur as a reflection of their specific habitat. Collections of cold-tolerant, salt-tolerant, and drought-tolerant types are examples. Rick (1962) indicated that in $L$. peruvianum there is a strong tendency for mountain races to be confined to the catchment area in which they are collected, with variation from watershed to watershed. $\mathrm{He}$ considered this variation related to edaphic conditions (Rick, 1986). The nature of these edaphic differences is not well-defined but may be related to $\mathrm{pH}$ and availability of nutrients.

Estimation of the elevation of collections is valuable as it provides the opportunity to evaluate rainfall and temperature conditions. Utility of collections could be improved by additional data. Portable $\mathrm{pH}$ and conductance meters are available and could be used to provide $\mathrm{pH}$ and soil solution conductance information. Both sets of data might provide insight into genetically useful types. Soil 
samples for chemical analyses would also be valuable. Assignment of Peruvian collections to the vegetative zones of Tosi (1960), using his ecological maps, would help correlate collections with rainfall data and temperatures. Assignment of location by approximate latitude and longitude would also be possible with these maps. Use of local place names can result in difficulty in locating specific sites for those unfamiliar with the area.

The wide range of variation in the tomato species habitats results in genetic material rich in diversity. Additional information on habitats of this material would provide the opportunity for greater discretion in selection of accessions for screening for suspected genetic characteristics.

\section{Literature Cited}

Bakun, A. and R.H. Parrish. 1982. Turbulence, transport, and pelagic fish in the California and Peru Current systems. Calif. Coop. Oceanic Fish. Invest. Rpt. 23:99-112.

Barry, R.G. and R.J. Chorley. 1987. Atmosphere weather and climate, 5th ed. Methuen. New York.

Cuartero, J., M.L. Gamez-Guillamon, and A. Diaz. 1985. Catalog of collections of Lycopersicon from Peruvian central areas. Tomato Genet. Coop. Rpt. 35:32-35.

Cuartero, J., F. Nuez, and A. Diaz. 1984. Catalog of collections of Lycopersicon and L. pennellit from northwest of Peru. Tomato Genet. Coop. Rpt. 34:43-46.

Delgado de la Flor B., F. 1988. Exploration y recoleccion de Lycopersicon spp. in la region sur del Peru. Tomato Genet. Coop. Rpt. 38:1921.
Flohn, H. 1969. Climate and weather. McGrawHill, New York.

Hone, M., C.M. Rick, and D.G. Hunt. 1978. Catalog of collections of green-fruited Lycopersicon species and Solanum pennellii found in watersheds of Peru L Tomato Genet. Coop. Rpt. 28:49-78

Hone, M., C.M. Rick, and D.G. Hunt. 1979 Catalog of collections of green-fruited Lycopersicon species and Solarium pennellii found in watersheds of Peru II. Tomato Genet. Coop. Rpt. 29:63-91.

Patterson, B.D. 1988. Genes for cold resistance from wild tomatoes. HortScience 23:794, 947.

Patterson, B.D. and L.A. Payne. 1983. Screening for chilling resistance in tomato seedlings. HortScience 18:340-341.

Rick, C.M. 1956. Genetic and systematic studies on accessions of Lycopersicon from the Galapagos Islands. Amer. J. Bot. 43:687-696.

Rick, C.M. 1962. Barriers to interbreeding in $L y$ copersicon peruvianum. Evolution 17:216-232.

Rick, C.M. 1963. Biosystematic studies on Galapagos tomatoes. Occasional papers Calif. Acad. Sci. 44:59-77.

Rick C.M. 1971. Lycopersicon, p. 468-471. In I.L. Wiggins and D.M. Porter (cds.). Flora of the Galapagos Islands, Stanford Univ., Palo Alto, Calif.

Rick, C.M. 1976a. Natural variability in wild species of Lycopersicon and its bearing on tomato breeding. Genet. Agr. 30:249-259.

Rick, C.M. 1976b. Tomato Lycopersicon esculentum (Solanacae), p. 268-273. In: N.W Simmonds (cd.). Evolution of crop plants. Longman, London.

Rick, C.M. 1978. Potential genetic resources in tomato species: Clues from observations in native habitats, p. 255-269. In: A.M. Srb (cd.). Genes, enzymes, and populations. Plenum, New York.
Rick, C.M. 1986. Reproductive isolation in the Lycopersicon peruvianum complex, p. 477-495. In: W.G. D'Arty (cd.). Solanaceae biology and systematic. Columbia Univ. Press, New York.

Rick, C.M. and S.D. Tanksley. 1981. Genetic variations in Solanum pennellii: Comparisons with two other sympatric tomato species. Plant Syst. Evol. 139:11-45.

Rick, C. M., E. Kesicki, J.F. Fobes, and M. Holle. 1976. Genetic and biosystematic studies on two new sibling species of Lycopersicon from interandean Peru. Theor. Applied Genet. 47:5568.

Rick, C.M., J.F. Fobes, and S.D. Tanksley. 1979. Evolution of mating systems in Lycopersicon hirsutum as deduced from genetic variation in electrophoretic and morphological characters. Plant Syst. and Evol. 132:279-298.

Rush, D.W. and E. Epstein. 1976. Genotypic responses to salinity. Plant Physiol. 57:162-166.

Tosi, J.A. 1960, Zonas de viola natural en el Peru. Memoria explicative sobre el mapa ecologico de] Peru. Boletin Tecnico 5. Inst. Interamer. de Ciencias Agricolas de la OEA Zona Andina.

U.S. Dept. of Commerce. 1966. World weather records 1951-1960, vol. 3. South America, Central America, West Indies, The Caribbean and Bermuda. U.S. Dept. Commerce, Washington, D.C.

U.S. Dept. of Commerce. 1982. World weather records 1961-70, vol. 3. West Indies, South and Central America. U.S. Dept. Commerce, Ashville, N.C.

Weberbauer, A. 1936. Phytogeography of the Peruvian Andes, p. 13-81. In: J.F. Macbride (cd.). Flora of Peru. Field Museum of Natural History Publ. 351. Bet. Ser. vol. 13.

Yu, A.T.T. 1972. The genetics and physiology of water usage in Solanum pennellii Corr. and its hybrids with Lycopersicon esculentum Mill. $\mathrm{PhD}$ Diss. Univ. of California, Davis. 